\title{
An overview of the status and conservation of the red panda Ailurus fulgens in India, with reference to its global status
}

\author{
Anwaruddin Choudhury
}

\begin{abstract}
The current status and distribution of the red panda Ailurus fulgens in the wild is poorly known. The subspecies fulgens is found in the Himalaya in Nepal, India, Bhutan, northern Myanmar and southwest China, and the subspecies styani occurs further to the east in south-central China. The red panda is an animal of subtropical and temperate forests, with the exception of Meghalaya in India, where it is also found in tropical forests. In the wild, red pandas take a largely vegetarian diet consisting chiefly of bamboo. The extent of occurrence of the red panda in India is about $170,000 \mathrm{sq} \mathrm{km}$, although its area of occupancy within this may only be about $25,000 \mathrm{sq} \mathrm{km}$. An estimate based
\end{abstract}

on the lowest recorded average density and the total area of potential habitat suggests that the global population of red pandas is about $16,000-20,000$. Habitat loss and poaching, in that order, are the major threats. In this paper the distribution, status and conservation problems of the red panda, especially in India, are reviewed, and appropriate conservation measures recommended, including the protection of named areas and the extension of some existing protected areas.

Keywords Ailurus fulgens, Himalaya, India, Meghalaya, red panda.

\section{Introduction}

The red or lesser panda Ailurus fulgens F. Cuvier (1825) is one of only two species of pandas, the other being the giant panda Ailuropoda melanoleuca David (1869) found only in China. Despite their popular names the two species are not closely related, and the red panda is now generally placed in the monotypic family Ailuridae (Glatston, 1994), although it has also been placed in the family Procyonidae. Compared with the giant panda, the red panda is smaller, has a longer tail and a different body colour, and the soles of its feet are covered in a dense mat of wool. Although this attractive mammal is well known to zoo visitors, its status and distribution in the wild are poorly known.

There are two subspecies, the nominate $A$.f. fulgens, which occurs in the Himalaya in Nepal, India, Bhutan, northern Myanmar and China (southern Tibet and western Yunnan), and A. f. styani, which is found further east in south-central China (Sichuan and Yunnan). The Salween ( $\mathrm{Nu}$ Jiang) river probably separates the two subspecies. The subspecies styani is distinguishable by its longer winter coat, darker body colour, larger skull, and more robust teeth (Ellerman \& MorrisonScott, 1966; Corbet \& Hill, 1992; Wei et al., 1998). Mitochondrial DNA studies examining levels of allelic

Anwaruddin Choudhury The Rhino Foundation, c/o The Assam Co. Ltd, G. Bordoloi Path, Bamunimaidam, Guwahati 781021, Assam, India. E-mail: badru1@sancharnet.in

Revised manuscript accepted for publication 15 March 2001 variation indicate that there are at least three red panda haplotypes, one of subspecies styani and two of subspecies fulgens (Glenn, pers. comm. in Sarich, 1976; Roberts, 1996).

In the wild, red pandas have a largely vegetarian diet consisting of young leaves and shoots of bamboo (their staple diet), fruits, roots, succulent grasses, acorns and lichens, and occasionally bird eggs, insects and grubs. Captive animals have shown particular interest in sweetened food and readily eat meat. The genera of bamboo that are most widely consumed include Arundinaria, Phyllostachys, Thamnocalamus, Chimonobambusa, Semiarundinaria, Pseudostachyum, and Qiongzhuea (Kocket al., 1989; Warnell et al., 1989; A. Choudhury, pers. obs.).

The 2000 IUCN Red List (Hilton-Taylor, 2000) categorizes the red panda as endangered on the basis of criteria $\mathrm{C} 2 \mathrm{a}$; i.e. that the population is estimated to be $<2500$ mature individuals (C), and that there is a continuing decline in numbers and population structure (2), with severe fragmentation, and with no subpopulation estimated to contain $>250$ mature individuals (a). However, there has been no comprehensive review of the status and conservation of the red panda. In this paper, I review the species' distribution, status and conservation problems, with particular reference to India, and make recommendations for appropriate conservation measures. Information obtained from published and unpublished sources and personal communications is referenced as appropriate, and all other information provided is a result of the surveys described below. 


\section{Surveys}

Review of the red panda's status in India is based on an extensive programme of field surveys in potential habitat (as part of a broader survey of wildlife in general), examination of preserved specimens, and interviews with villagers, hunters, graziers and forest officials. I conducted surveys in Arunachal Pradesh in 1990 (April, July), 1991 (March), 1992 (September, December), 1993 (January-March, May, June, August, December), 1994 (January-April, October, November), 1995 (April), 1997 (November), 1998 (April, July, August, November), 1999 (April, July, October, December) and 2000 (May, October), in Meghalaya in 1995 (October), 1996 (April), 1997 (April), 1998 (August) and 2000 (December), in northern West Bengal in 1995 (June, July, October, November), 1996 (August, September, December), and 1999 (May), and on the borders with Sikkim in 1995 (July), making a total of 147 days in the field. Data for areas outside India were obtained mostly from published sources, supplemented by short visits. I conducted surveys, totalling 16 days, in Bhutan in 1985 (October), 1986 (March), 1996 (January, March, April, November) and 2000 (May, June, September), in Nepal in 1996 (February, December), and in northern Myanmar in 1994 (February).
The presence or absence of the red panda in an area was ascertained by sightings (nine occasions in Arunachal Pradesh), droppings (at four sites in Arunachal Pradesh), examination of preserved skins (five in Arunachal Pradesh and two in Meghalaya) and a stuffed specimen (from Bhutan), and live specimens (seven in Arunachal Pradesh) in captivity in villages. Surveys were made both during the day and continuing after dusk, on foot along paths and trails, and sometimes also by vehicle along roads and motorable tracks. It should be noted that the shy and secretive nature of the red panda, and its largely nocturnal habits, make observations difficult. Daytime observations were made with the aid of binoculars and $10 \times 50$ and $10 \times 46$ telescopes.

\section{Distribution}

The red panda is found in the Himalaya in Nepal, India, Bhutan, Myanmar and southern China, with a disjunct population on the Meghalaya Plateau of north-eastern India (Fig. 1). Its westernmost occurrence is in Mugu District, western Nepal $\left(82^{\circ} \mathrm{E}\right)$, and its easternmost in the Minshan Mountains and upper Min Valley of Sichuan Province, south-central China $\left(104^{\circ} \mathrm{E}\right)$. The north-south extent of its distribution is narrower, from southern parts of the Gaoligong Shan on the Myanmar-China

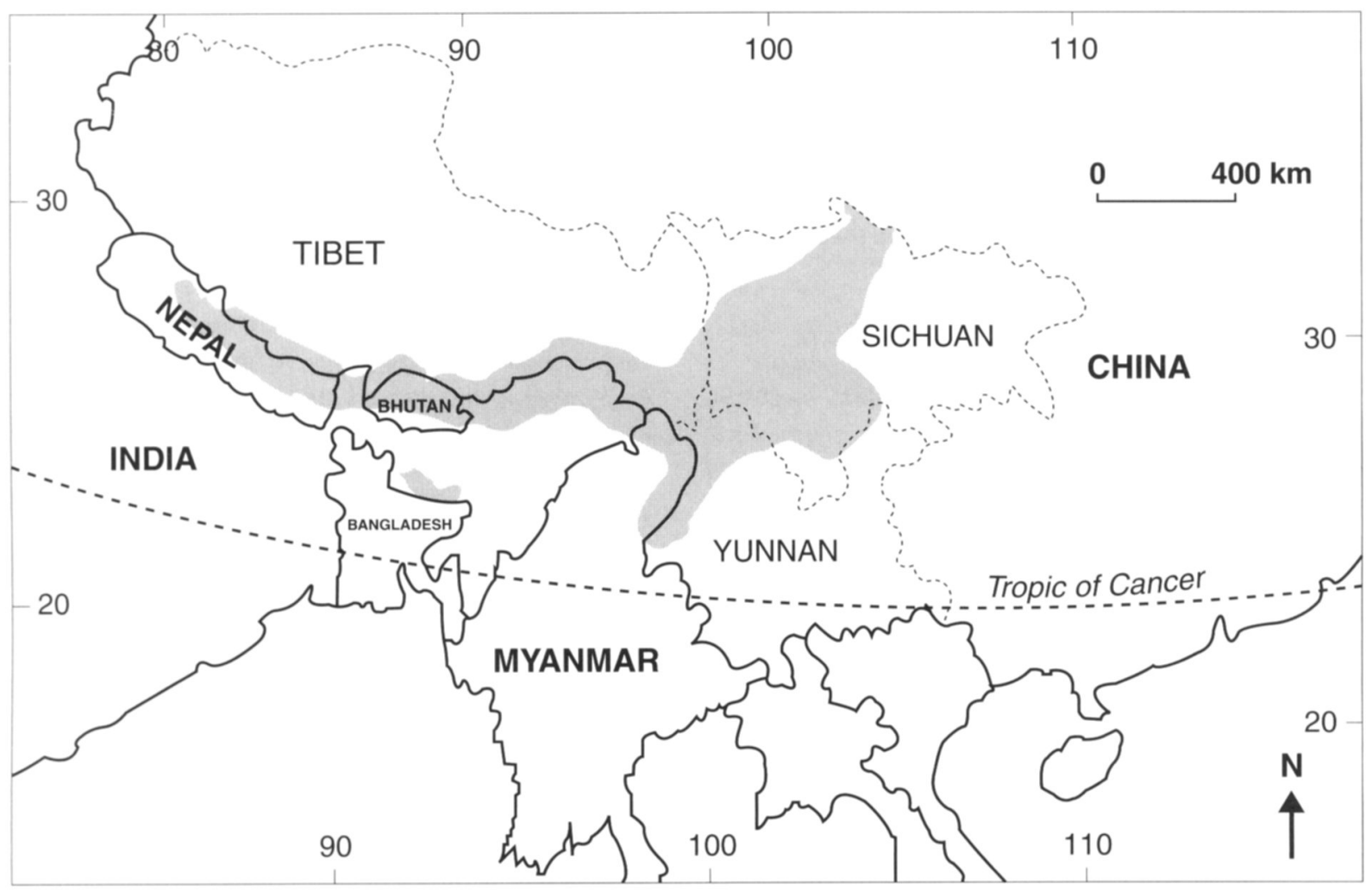

Fig. 1 The global distribution (shaded area) of the red panda Ailurus fulgens. 
border $\left(25^{\circ} \mathrm{N}\right)$ to Minshan Mountains and upper Min Valley, Sichuan $\left(33^{\circ} \mathrm{N}\right)$ (Ellerman \& Morrison-Scott, 1966; Macdonald, 1984; Corbet \& Hill, 1992; Choudhury, 1997).

In Nepal it is found in eight out of the country's 14 Zones: Karnali, Dhaulagiri, Gandaki, Bagmati, Janakpur, Sagarmatha, Kosi and Mechi. It might also occur in two more zones, Bheri and Rapati (Department of National Parks \& Wildlife Conservation, Nepal). In Bhutan it is found all along the Middle Himalaya and the slopes of the Greater Himalaya. There are recent sightings from Jigme Dorji and Thrumshing La National Parks (U. Lhendup, pers. comm.), and I examined a stuffed specimen from Sakteng Wildlife Sanctuary. In Myanmar the species is restricted to the northern mountains bordering India and China, especially Gaoligong Shan and areas north of Putao (Rabinowitz \& Khaing, 1998).
Although formerly distributed widely in central and south-central China, including western Sichuan and Yunnan, southern Shanxi and Gansu, northern Guizhou, and in south-west Tibet and Qinghai Provinces, the species is today confined to parts of Sichuan, Yunnan and Tibet (Feng et al., 1986; Wei et al., 1998). In India, the red panda is confined to the north-east in Sikkim, northern West Bengal and Arunachal Pradesh, with an isolated population in Meghalaya (Fig. 2) (Finn, 1929; Prater, 1948; Gee, 1964; Choudhury, 1996, 1997). Its distribution range in individual states is as follows:

\section{Sikkim}

The red panda is found in all districts. In protected areas it has been recorded by the Forest Department in Kangchendzonga National Park, and Fambong Lho,

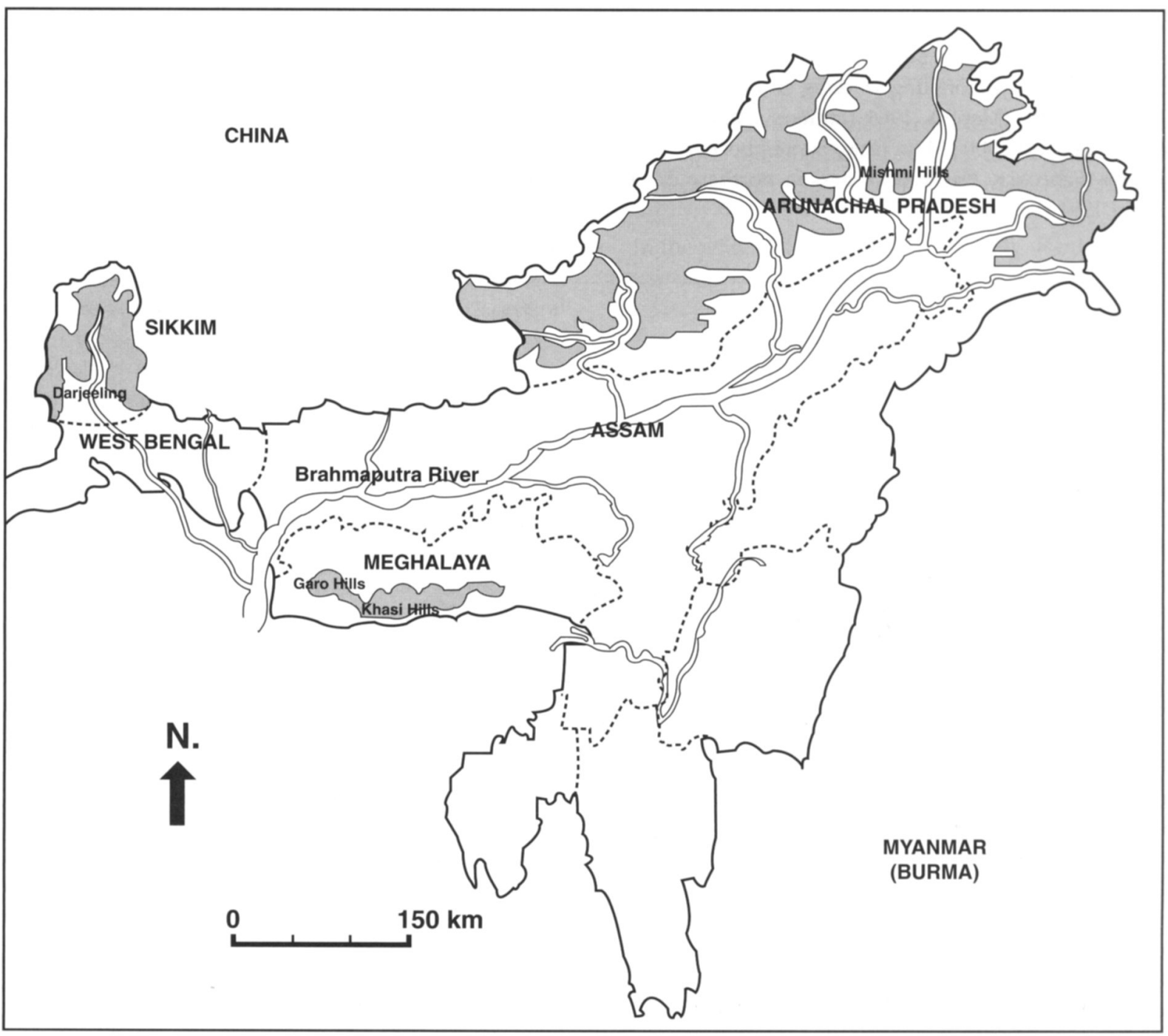

Fig. 2 The distribution (shaded area) of the red panda Ailurus fulgens in India. 
Kyongnos La Alpine, Shingba Rhododendron, Barsey Rhododendron, and Maenam Wildlife Sanctuaries.

\section{West Bengal}

The red panda is found only in Darjeeling District, where it is mostly confined to the protected areas of Neora Valley and Singalila National Parks and adjacent areas.

\section{Arunachal Pradesh}

The red panda is more widely distributed in Arunachal Pradesh than in any other Indian State. The species is found in the Himalaya and Mishmi Hills in 11 of the State's 13 districts (Changlang, Dibang Valley, East Kameng, East Siang, Lohit, Lower Subansiri, Upper Siang, Upper Subansiri, West Kameng, West Siang and Tawang). Possible occurrence of red pandas in Papum Pare District requires investigation. In protected areas it has been recorded in Mouling and Namdapha National Parks, and Dibang, Eaglenest, Mehao, Sessa Orchid, and Kamlang Wildlife Sanctuaries, and possibly in Taley Valley Wildlife Sanctuary. Its presence in the higher areas of Pakhui Wildlife Sanctuary is yet to be confirmed.

\section{Meghalaya}

The red panda is mainly confined to two small areas: Nokrek National Park, which covers part of West, East and South Garo Hills Districts, and Balpakram National Park of South Garo Hills District (Choudhury, 1997) and the adjacent forests of West Khasi Hills District. It also occurs further east in the Mawsynram Development Block area of East Khasi Hills District. This disjunct population in Meghalaya is separated from the main range by a significant zoogeographic barrier in the form of the Brahmaputra river. This river has prevented the dispersal of a number of terrestrial and arboreal mammals, notably the hoolock gibbon Hylobates hoolock, stump-tailed macaque Macaca arctoides and pig-tailed macaque $M$. nemestrina (Choudhury, 1989), which are confined to the south bank. The known distribution pattern of the red panda suggests that, following its origin in the extreme north-eastern corner of present-day India (the Mishmi Hills) and adjacent areas of south-eastern Tibet (Tedford \& Gustafson, 1977; Kurt'en \& Anderson, 1980; Roberts \& Gittleman, 1984; Martin, 1989), it may have reached Meghalaya through dispersal to the southwest (Fig. 2), i.e. following the alignment of the Patkai and Naga ranges to the Garo Hills, the western end- point of the mountains to the south of the Brahmaputra river.

\section{Ecology}

Habitat

The red panda is an animal of subtropical and temperate forests, with the exception of Meghalaya where it is also found in tropical forests. Bamboo brakes (thickets), especially of the ringal bamboo Arundinaria spp., are a favoured habitat type. Although Roberts \& Gittleman (1984) recorded the species' altitudinal range as being only above $2200 \mathrm{~m}$, it can be found at $1500-4800 \mathrm{~m}$ and almost up to the summer snowline at $5000 \mathrm{~m}$. In Meghalaya, however, it is found at elevations of 700-1400 $\mathrm{m}$ (Choudhury, 1997), and exceptionally on 28 January 1997 was observed at $200 \mathrm{~m}$ in Siju Sanctuary, adjacent to Balpakram National Park (Surajit Roy, pers. comm.). In Darjeeling, most of the surviving individuals are found above $2000 \mathrm{~m}$ because habitat in lower areas has been badly degraded.

The extent of occurrence (sensu Hilton-Taylor, 2000) of the red panda in India is an area of about $170,000 \mathrm{sq} \mathrm{km}$, although its area of occupancy (sensu Hilton-Taylor, 2000) - the area within its extent of occurrence that it occupies - is only about $25,000 \mathrm{sq}$ $\mathrm{km}$ (Table 1). The area of occupancy of the red panda is more-or-less equivalent to areas of potential habitat, although within these areas the species appears to have a preference for particular habitat types. Studies of the giant panda in China suggested that only about half (49.1 per cent) of the potential habitat is actually used. The habitat requirements of the giant panda have been found to be similar to that of the red panda (Wang, 1989; Wei, 1997), and so the actual area of suitable habitat in India could be as little as $12,400 \mathrm{sq} \mathrm{km}$.

Observations in Langtang National Park, Nepal, indicated that proximity to water may be an important habitat requirement because 90 per cent of droppings were found within $100 \mathrm{~m}$ of the nearest source of water (Yonzon \& Hunter, 1991). The red panda's preference for particular habitats was also illustrated by the same study. Of the five vegetation types sampled in the park, i.e. fir-jhapra bamboo, rhododendron, broad-leaved-raate, birch and alpine scrub, fir-jhapra was preferred (92 per cent of radio locations).

Globally, the total potential habitat of the species is about $142,000 \mathrm{sq} \mathrm{km}$, with China alone accounting for more than half. 


\begin{tabular}{llcc}
\hline Country & Area or State & $\begin{array}{l}\text { Potential habitat } \\
\text { (sq km) }\end{array}$ & $\begin{array}{l}\text { Habitat probably used (based } \\
\text { on } 49.1 \text { per cent of potential } \\
\text { habitat, see text for details) }\end{array}$ \\
\hline India & Arunachal Pradesh & 23,000 & 11,300 \\
& Meghalaya & 600 & 300 \\
& Sikkim & 1700 & 800 \\
& West Bengal & 200 & 100 \\
& (Darjeeling District) & & \\
China & Total & 25,500 & 12,500 \\
& Sichuan & 35,100 & 17,200 \\
& Yunnan & 21,700 & 10,600 \\
& Tibet & 19,500 & 9600 \\
Nepal & Total & 76,300 & 37,400 \\
Bhutan & & 16,700 & 8200 \\
Myanmar & & 10,900 & 5400 \\
Total & & 13,000 & 6400 \\
\hline
\end{tabular}

Table 1 Potential area of habitat of the red panda. Sources: India, own estimate based on forest cover maps of Forest Survey of India, State of Forest Report 1997 and Forest Department maps, in combination with field visits to known panda areas; China, Wei et al. (1998); Nepal, estimated from data of Department of National Parks \& Wildlife Conservation, Nepal; Bhutan, estimated from data of WWF-Bhutan Programme; Myanmar, estimated from data of World Conservation Monitoring Centre, Cambridge, UK.

\section{Population status}

It is difficult to estimate population densities of an animal that is as shy and secretive as the red panda, and the nature of its preferred habitat exacerbates the difficulty. The only available information for the species in India is an estimate of one animal per $3.9 \mathrm{sq} \mathrm{km}$ for Singalila National Park and adjacent areas (Bahuguna et al., 1998). In part of Langtang National Park in Nepal, density was estimated as one animal per $2.0-11.0 \mathrm{sq} \mathrm{km}$, with averages of one per 2.8 and $4.4 \mathrm{sq} \mathrm{km}$ in 1986 and 1987, respectively (Yonzon \& Hunter, 1991). The maximum number that have been sighted together was eight animals feeding at night in a single bamboo clump, approximately $15 \mathrm{~km}$ from '0 point' on Wakro-Deban Road in Lohit District, Arunachal Pradesh in 1992 (M. Kashyap, pers. comm.). This was perhaps a case of two or more family groups feeding together.

Population density in the western sector of its distribution in Nepal appears to be low in comparison with eastern areas such as Arunachal Pradesh. In the northernmost parts of Myanmar, especially in the proposed Hkakabo-Razi Protected Area, the red panda is relatively common (Rabinowitz \& Khaing, 1998). In Arunachal Pradesh, local reports and capture records indicate that it is relatively common in Tawang and northern West Kameng Districts and in Mishmi Hills, especially Dibang Valley and Lohit Districts.

Taking the lowest recorded average density of one panda per $4.4 \mathrm{sq} \mathrm{km}$ gives an estimated 5000-6000 animals in India, with the greatest numbers being in Arunachal Pradesh. An estimate of 6000-7000 red pandas in China (Wei et al., 1998) gives an estimated global population of 16,000-20,000 (including Bhutan, Nepal and Myanmar).

\section{Potential competitors}

Primates, such as the Assamese macaque Macaca assamensis, stump-tailed macaque, capped langur Presbytis pileata, golden langur $P$. geei and hoolock gibbon take bamboo shoots and leaves, and are thus potential competitors of the red panda. Other species that also eat bamboo are the takin Budorcas taxicolor, sambar Cerous unicolor, elephant Elephas maximus, wild pig Sus scrofa and porcupine Hystrix brachyura. The bamboo rats Rhizomys pruinosus and Cannomys badius are also, like the red panda, specialist bamboo feeders, and they occur in the same habitat. In Meghalaya and lower areas of Arunachal Pradesh, hornbills (family Bucerotidae) might compete with the red panda for nesting sites, as both favour natural hollows in old trees.

\section{Threats}

\section{Habitat destruction}

The red panda is probably threatened throughout its range by the degradation, destruction and fragmentation of its forest habitat (Plate 1), the major causes of which are commercial logging, demand for firewood (especially in the cold Himalaya), clearing for habitation and farming, jhum (slash-and-burn shifting cultivation) by hill tribes, grazing of domestic stock, monoculture forest plantation, and various developmental activities. Both legal and illegal felling of old-growth trees is occurring throughout the panda's range in India, and in the Khasi Hills of Meghalaya some of the best panda habitat is privately owned, potentially making conservation efforts difficult. 
Between 1980 and 1995 the number of tourists visiting Sikkim annually rose from 1000 to 100,000 (Mahapatra, 1998), and their requirement for wood for both cooking and heating has accelerated habitat loss. This is also the case in the Singalila area of Darjeeling and in Nepal. At the same time the high growth rate of the local human population, which almost doubled between 1971 and 1991 (the last year for which census data are available), increased the pressure on land for both housing and farming, as well as increasing the demand for firewood.

In Arunachal Pradesh and Meghalaya, and also in parts of Myanmar and China, the hill tribes practise jhum, a form of shifting slash-and-burn cultivation that destroys large tracts of forest. In earlier times, one jhumcycle (i.e. the time to return to an abandoned area) was $>20$ years, but because of the growth of the human population and the scarcity of suitable land, the cycle has decreased to 4-6 years. Overgrazing by domestic stock, especially yaks in Sikkim and higher areas of Arunachal Pradesh (and also in Bhutan, Nepal and parts of China) contributes to habitat degradation.

Forest fires, although not usually a serious problem in red panda habitat, was the cause of extensive damage to bamboo brakes in parts of western Arunachal Pradesh in 1999. Lack of winter rain had made the forest, including bamboos, unusually susceptible to fire, which probably originated from jhumiyas or hunters' camp fires.

From the latter part of the 19th century onwards, large forested areas of Darjeeling District were cleared for commercial tea plantation; these areas included much potential panda habitat. Various developmental activities have also destroyed potential red panda habitat, largely through requirements for wood for construction and heating, with the expansion of townships such as Tawang in Arunachal Pradesh, after it was declared a District Headquarters, being a typical example.

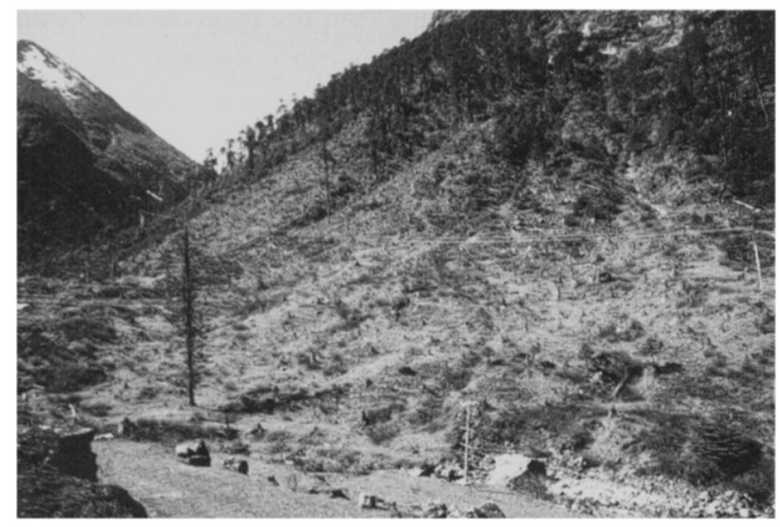

Plate 1 Large-scale felling in temperate forest, such as this in Nuranang Valley, Arunachal Pradesh, is the major threat to the red panda's habitat.
Road construction in Sikkim and Arunachal Pradesh over the past two decades has affected large areas of forest. Construction of new roads involves large-scale felling of trees, and erosion following construction, and sometimes landslides, can cause further habitat loss. In addition, labourers engaged in road-construction are known to resort to logging both for firewood and for wood-smuggling. Unfortunately the construction of new roads opens up formerly inaccessible areas for both legal and illegal logging.

Destruction of forest has resulted in the fragmentation of habitat into smaller patches or forest 'islands', which not only affects the movement of largely arboreal animals such as the red panda, but potentially results in inbreeding and loss of genetic variation. Moreover, once movement over larger areas ceases, bamboo flowering (following which the plants die) in any fragment may result in starvation of the pandas. In Darjeeling, the red panda is now confined to two areas that are separated from each other (although both are as yet contiguous with forests in Nepal and Bhutan). An alarming decrease in forest cover is evident in Meghalaya, where the dense forest cover was reduced from 33.1 per cent in 1980-82 (National Remote Sensing Agency, Hyderabad) to 18 per cent in 1993 (FSI, 1997). In just 2 years, from 1989-90 to 1991-92, Arunachal Pradesh lost $334 \mathrm{sq} \mathrm{km}$ of dense forest (FSI, 1993, 1995).

\section{Poaching and trade}

Hunting does not appear to be as serious a threat as habitat loss and, at least in Arunachal Pradesh and Meghalaya, hunters do not appear to deliberately seek out the red panda. However, it is shot opportunistically and caught accidentally in snares during hunting for wild pig, deer, goat-antelopes (serow, goral and takin) and primates. It is possible that forest degradation is making the species more visible to hunters. The tribes of Arunachal Pradesh, Meghalaya and northern Myanmar will eat the meat of any red pandas caught, and the pelt is preserved, usually for its attractiveness rather than for sale. I have, however, occasionally seen pelts for sale in Tawang in Arunachal Pradesh, where some people also wear a hat made of red panda fur.

I was not able to detect any systematic trade in red pandas in Arunachal Pradesh or Meghalaya, and although the species was formerly trapped in Nepal, Darjeeling, northern West Bengal and Sikkim for sale to zoos - which might account for the general rarity of the species in these areas - this does not appear to be the case now. Bahuguna et al. (1998) estimated that at least 300 red pandas were trapped for trade in the 1960s in Singalila. In China, red panda pelts can be found in many local markets (Glatston, 1994). 
Munro (1969) reported handling 350 red pandas sold to zoological gardens within a span of 17 years, suggesting that there was regular trapping of live animals in some parts of their range. Such trade largely stopped following the listing of the red panda on CITES Appendix I (Traffic, 1991; Lu et al., 1993). The last legal export of wild-caught animals from Nepal was in 1984, but illegal trapping is sometimes still reported. Glatston (1994) noted one animal dealer who in 1990 offered a pair of red pandas for sale that had reputedly been born in captivity in Bangladesh, although there is no such breeding record in that country. It has been reported that in northernmost Myanmar, red panda skins are purchased by Chinese traders (Rabinowitz \& Khaing, 1998). I saw the red panda occasionally kept as a pet in Sikkim and Arunachal Pradesh, generally as a result of the opportunistic capture of young animals.

\section{Conservation measures}

\section{Legal protection}

As well as its listing in Appendix I of CITES, the red panda is protected under Schedule I of the Indian Wild Life (Protection) Act 1972, which prohibits its killing or capture dead or alive. This is the highest legal protection status that can be given to any species in India. However, enforcement, especially outside protected areas, is virtually non-existent. The red panda is also legally protected in Bhutan, China and Nepal (Glatston, 1994).

\section{Habitat protection}

There are 20 protected areas in India, covering a total of approximately $11,778 \mathrm{sq} \mathrm{km}$, that have known or possible populations of the red panda (Table 2). The greatest proportion of this area, about 78 per cent, lies in the State of Arunachal Pradesh, within which Dibang Wildlife Sanctuary (4149 sq km) is the largest Sanctuary in India that contains a population of red pandas. Not all of the parts of the protected areas provide suitable habitat for the species, and thus these protected areas cover only about one-third of the total potential panda habitat in India.

Protection for the red panda is more or less adequate within these protected areas, largely because of their remoteness and the difficulty of the terrain, rather than to actual enforcement of their legally protected status. It needs to be noted, however, that major parts of the interior of the larger protected areas of Kangchendzonga, Dibang and Namdapha are completely unstaffed, and hence
Table 2 Protected areas in India, by State, with known and possible $^{a}$ red panda populations.

\begin{tabular}{|c|c|c|}
\hline State & Protected area & Area $(\mathrm{sq} \mathrm{km})$ \\
\hline \multirow[t]{10}{*}{ Arunachal Pradesh } & Dibang WS & 4149 \\
\hline & Eaglenest WS & 217 \\
\hline & Kamlang WS & 783 \\
\hline & Mehao WS & 282 \\
\hline & Mouling NP & 483 \\
\hline & Namdapha NP & 1985 \\
\hline & Pakhui WS ${ }^{a}$ & 862 \\
\hline & Sessa Orchid S & 100 \\
\hline & Taley Valley $W^{a}{ }^{a}$ & 337 \\
\hline & Total & 9198 \\
\hline \multirow[t]{4}{*}{ Meghalaya } & Balpakram NP & $312^{b}$ \\
\hline & Nokrek NP & 48 \\
\hline & Siju WS & 5 \\
\hline & Total & 365 \\
\hline \multirow[t]{7}{*}{ Sikkim } & Barsey Rhododendron S & 104 \\
\hline & Fambong Lho WS & 52 \\
\hline & Kangchendzonga NP & 1784 \\
\hline & Kyongnos La Alpine S & 31 \\
\hline & Maenam WS & 35 \\
\hline & Shingba Rhododendron S & 43 \\
\hline & Total & 2049 \\
\hline \multirow[t]{3}{*}{ West Bengal } & Neora Valley NP & 88 \\
\hline & Singalila NP & 79 \\
\hline & Total & 167 \\
\hline Total & & 11,779 \\
\hline
\end{tabular}

NP: National Park; S: Sanctuary; WS: Wildlife Sanctuary.

${ }^{b}$ There were some anomalies in land acquisition and the actual area is less than $200 \mathrm{sq} \mathrm{km}$. Sources: Forest Departments of Arunachal Pradesh, Meghalaya, Sikkim and West Bengal.

there is currently no chance of detection of any trapping or hunting that could be occurring

Outside India, China has 35 protected areas (totalling $>51,491 \mathrm{sq} \mathrm{km})$, Nepal has eight $(19,838 \mathrm{sq} \mathrm{km})$ and Bhutan five ( $>8000 \mathrm{sq} \mathrm{km}$ ) that support known or reported panda populations (the major areas are listed in Table 3). Quomolangma Nature Reserve in Tibet $(35,000 \mathrm{sq} \mathrm{km})$ is the largest protected area in red panda habitat, although the bulk of this reserve is not suitable for the species because it is under permanent snow cover (Mt Everest lies partly within this reserve). The largest contiguous protected area network in the range of the species $(44,000 \mathrm{sq} \mathrm{km})$ covers parts of Nepal (Sagarmatha, Langtang and Makalu-Barun National Parks, and Kanchenjunga Conservation Area), China (Quomolangma Nature Reserve) and India (Kangchendzonga National Park) although the actual red panda habitat within this region may be very small (Green, 1993; Wei et al., 1998). 
Table 3 Major protected areas $(>300 \mathrm{sq} \mathrm{km}$ ) in Nepal, Bhutan and China with known and possible ${ }^{a}$ red panda populations, based on Green (1993), Wei et al. (1998) and on information provided by the Department of National Parks \& Wildlife Conservation, Nepal and the WWF-Bhutan Programme.

\begin{tabular}{|c|c|c|c|}
\hline Country & Region & Protected area & Area $(\mathrm{sq} \mathrm{km})$ \\
\hline \multirow[t]{5}{*}{ Bhutan } & & Black Mountains NP & 1723 \\
\hline & & Jigme Dorji NP & 4230 \\
\hline & & Bumdeling WS & 1182 \\
\hline & & Sakteng WS & $\mathrm{NA}$ \\
\hline & & Thrumshing La NP & 748 \\
\hline \multirow[t]{14}{*}{ China } & Sichuan & Baiyang NR & 583 \\
\hline & & Fengtongzhai NR & 400 \\
\hline & & Huanglongsi NR & 400 \\
\hline & & Jiuzhaigou NR & 600 \\
\hline & & Mabian Dafengding NR & 300 \\
\hline & & Moshui NR & 318 \\
\hline & & Wolong NR & 2000 \\
\hline & & Wujiao NR & 371 \\
\hline & Yunnan & Baimaxueshan NR & 1880 \\
\hline & & Gaoligongshan NR & 1239 \\
\hline & & Nujiang NR & 3254 \\
\hline & Tibet & Mangkang Golden Monkey NR & 1853 \\
\hline & & Medog NR & 626 \\
\hline & & Quomolangma NR & 35,000 \\
\hline \multirow{7}{*}{ Nepal } & & Annapurna Conservation Area & 7629 \\
\hline & & Dhorpatan Hunting Reserve & 1325 \\
\hline & & Kanchenjunga Conservation Area & 2035 \\
\hline & & Langtang NP & 1710 \\
\hline & & Makalu-Barun NP \& Buffer Zone & 2330 \\
\hline & & Sagarmatha NP & 1148 \\
\hline & & Shey-Phoksundo NP ${ }^{a}$ & 3555 \\
\hline
\end{tabular}

NP: National Park, NR: Nature Reserve, NA: information not available.

\section{Conservation recommendations}

\section{Expansion and strengthening of the protected area network}

To counter the present effects of the degradation and fragmentation of the red panda's forest habitat, more areas need to be brought into the protected area network and some of the protected areas need to be expanded, especially in Arunachal Pradesh and Meghalaya. I make the following recommendations, which would bring under protection an additional $6000 \mathrm{sq} \mathrm{km}$ with good forest cover and known populations of the red panda.

In Arunachal Pradesh the areas of Magu (450 sq km, in Tawang District) and Walong (1200 sq km, in Lohit District) to be National Parks, and the areas of Geshila (80 sq km), Tawang (60 sq km) (both in Tawang District), Lada (1000 sq km, West and East Kameng Districts), Ditchu (Di Chu) (1792 sq km, in Lohit District), and the uninhabited upper areas of Lower and Upper Subansiri Districts (>2000 sq $\mathrm{km}$ ) to be Wildlife Sanctuaries. In Meghalaya I recommend the following areas as Wildlife Sanctuaries: approximately $50 \mathrm{sq} \mathrm{km}$ in West Khasi Hills District in the catchment area of the Jadukata river, and Trongpleng (25 sq $\mathrm{km}$ ) in East Khasi Hills District.

In Arunachal Pradesh an area of $15 \mathrm{sq} \mathrm{km}$ between Eaglenest Pass and Lamacamp could be added to Eaglenest Wildlife Sanctuary. Mouling National Park could have an additional area of $900 \mathrm{sq} \mathrm{km}$ towards the north, north-west and west. Kamlang Wildlife Sanctuary could have an additional $600 \mathrm{sq} \mathrm{km}$ of the Kamlang Reserved Forest. In Meghalaya the Balpakram National Park should be extended to include about $100 \mathrm{sq} \mathrm{km}$ of West Khasi Hills District. In northern West Bengal, Singalila National Park in Darjeeling District could be extended to include an additional area of about $96 \mathrm{sq} \mathrm{km}$ of contiguous reserved forest.

In general, protection measures in most of the national parks and wildlife sanctuaries are inadequate, especially in the larger areas. In remote regions of Eaglenest, Kangchendzonga, Neora Valley, Mouling, Dibang and Namdapha, most of the areas are unmanned and the occasional poaching (e.g. by the Lisu people in eastern areas of Namdapha and Idu Mishmis in Mehao and Dibang Sanctuaries) goes unreported. There is an urgent need to set up ranger camps in the interior of these protected areas, and to be able to adequately assess 
poaching trends there is a need to involve local volunteers and village headmen in conservation programmes.

\section{Prevention of illegal felling, control of jhum cultivation} and overgrazing

It will not be possible to bring all of the potential red panda habitat areas into the protected area network, and so attention needs to be given to those factors that are causing habitat degradation in other areas. The two major threats are illegal tree felling, especially in Arunachal Pradesh and Meghalaya, and uncontrolled jhum cultivation. Efforts need to be made to reduce the intensity of jhum cultivation by the promotion of additional terraced cultivation. The Integrated Jhumiya Development Programme (IJDP) of the Government of India should be extended to include the involvement of local NGOs. Overgrazing by domestic yaks in high elevation areas is also contributing to habitat degradation (one yak generally requires $30 \mathrm{~kg}$ of fodder per day), but this could possibly be reduced by providing graziers (locally called chauries) with other occupations such as tourist guides.

\section{Tourism, public awareness and enforcement}

Whilst tourism should be encouraged to provide local income, it needs to be regulated. In particular, tour operators and hotels should be required to use cooking gas and kerosene rather than wood fuel. Most villagers within the red panda's range in India are not yet aware of the legal status of the species, and therefore conservation of the red panda could benefit greatly from public awareness campaigns, possibly led by the Forestry Department and NGOs, and stricter enforcement of the protection afforded to the species by the Indian Wild Life (Protection) Act.

\section{Conclusions}

The red panda Ailurus fulgens is still widely but sparsely distributed in its known range from the central Himalaya of Nepal to southern China, Tibet and northern Myanmar, with a disjunct population on the Meghalaya Plateau of India to the south of the Brahmaputra river. In India the species is confined to the north-eastern part of the country, with the greater part of its range being in the state of Arunachal Pradesh. In Meghalaya the red panda is living in tropical and subtropical forests, whereas elsewhere within its range it is known only from temperate and subtropical forest habitats.

Whilst the greatest threats to the red panda come from the destruction, degradation and fragmentation of its forest habitat, and to a lesser extent from poaching, the ultimate cause of the threats is the high growth rate of the human population within the species' range and nearby areas. Although the species is protected under Schedule I of the Indian Wild Life (Protection) Act, 1972, the highest protection status that can be afforded to a species in India, enforcement, especially outside protected areas, is virtually non-existent. Long-term conservation of the red panda requires both the legal protection of more areas of forest habitat and the enforcement of protection in existing conservation areas, in particular the provision of an adequate infrastructure for protected areas and control of tree felling and poaching.

Although the 2000 IUCN Red List (Hilton-Taylor, 2000) categorizes the global status of the red panda as endangered on the basis of criteria $\mathrm{C} 2 \mathrm{a}$, the global population may be $16,000-20,000$, in which case the number of mature individuals will be $>2500$. However, the data presented here suggest that the red panda should be categorized as Endangered based on criteria A1c; i.e. population reduction (A), most probable of at least 50 per cent over the last 10 years (1), based on a decline in area of occupancy and quality of habitat (c).

\section{Acknowledgements}

I am indebted to WWF-India for supporting this review of the current status of the red panda. I thank Samar Singh, former Secretary-General, and Dr A.R.K. Shastry, Director (BHCP). I would like to thank the following Forest department officials for their assistance during this study. Meghalaya: S.B. Singh, T. Deb Roy, J. Datta, P.R. Marak, L. Ao, T. Rani and E. Lyngdoh. Arunachal Pradesh: Late R.P. Neog, Yogesh, A. Sen, C. Reddy, M. Negi, Pratap Singh, M.K. Palit, P. Das, Dewri, S.K. Shome, T. Hazarika, Moniram Gogoi, Dorji Raptan, Rajesh Pachung, Srimanta Tamuli, Ratnesh Rai, Pemba Tamang, K. Tamang, Amit Glow and other staff based at Miao, Deban, Wakro, Roing, Mayodia, Dambuk, Ziro, Tawang, Ramalingam and Sundarview. Northern West Bengal: the staff based at Lava and Kalimpong. I also thank the following for their help and encouragement during this study. Meghalaya: Wife of Dr Lau of Tura for allowing me to examine the skin in their possession, George Richmond, Babar Ali, R. Sarkar and M. Sarki. Assam: Ms Emily Chowdhary, former Dev. Commissioner for Hill Areas, Nur Husain, Dr Atul Borgohain, Dilip Handique, late Sakul Boro, Babul Debnath, Faizul Ali, Hakeem Choudhury, Bisoy Boro, Moniram Boro, Ratul Talukdar, Nitu Phukan and many others. Arunachal Pradesh: Bir Bahadur Gurung, Leto Mili of Dambuk, wife of B.C. Hazarika, Munu Kashyap, Dr P. Dewri, Sonu Sonar, Lobsan Chander, Darge and Dr Tacho. Northern West Bengal: S. Datta, Lt. Col. S. Banerjee, 
Dr S. Bhattacharyya, Ms Abhoya Bose and Gour Gopal Biswas. Bhutan: Dr Charles McDougal and Ugyen Lhendup. S. Chatterjee, A.K. Goswami, R. Awasthi and S. Dey, all of WWF, extended help during various stages and I thank them. Thanks are also due to $S$. Molur. Special thanks are due to Dr Angela Glatston for sending all of her publications, and to my family who supported me in many ways during this study.

\section{References}

Bahuguna, C., Dhaundyal, S., Vyas, P. \& Singhal, N. (1998) The red panda at Singalila National Park and adjoining forest: a status report. Small Carnivore Conservation, 19, 11-12.

Choudhury, A.U. (1989) Primates of Assam: their distribution, habitat and status. PhD thesis, Gauhati University, Guwahati. Choudhury, A.U. (1996) Red panda in Garo hills. Environ, 4, 21.

Choudhury, A.U. (1997) Red panda Ailurus fulgens F. Cuvier in the north-east with an important record from Garo hills. Journal of the Bombay Natural History Society, 94, 145-147.

Corbet, G.B. \& Hill, J.E. (1992) The Mammals of the Indomalayan Region: A Systematic Review. Oxford University Press, Oxford.

Cuvier, F. (1825) Histoire Naturelle des Mammiferes avec des Figures Originales. Colorees, Desinees d'Apris des Animaux Vivants, 1824-42, vol. 2, pp. 1-3. Paris.

David, A. (1869) Voyage en Chine. Nouvelles Arch. Museum Histoire Naturelle Paris Bulletin, 5, 1-13.

Ellerman, J.R. \& Morrison-Scott, T.C.S. (1966) Checklist of Palaearctic and Indian Mammals, 1758-1946, 2nd edn. British Museum (Natural History), London.

Feng, Z., Cai, G. \& Zheng, C. (1986) Mammals in Tibet. Science Press, Beijing [in Chinese].

Finn, F. (1929) Sterndale's Mammalia of India. Thacker, Spink, Calcutta \& Simla.

FSI (1993) State of Forest Report. Forest Survey of India (FSI), Dehra Dun.

FSI (1995) State of Forest Report. Forest Survey of India (FSI), Dehra Dun.

FSI (1997) State of Forest Report. Forest Survey of India (FSI), Dehra Dun.

Gee, E.P. (1964) The Wild Life of India. Collins, London.

Glatston, A.R. (compiler) (1994) Status Survey and Conservation Action Plan for Procyonids and Ailurids:. The Red Panda, Olingos, Coatis, Raccoons, and their Relatives. IUCN, Gland, Switzerland.

Green, M.J.B. (compiler) (1993) Nature Reserves of the Himalaya and the Mountains of Central Asia. IUCN \& Oxford University Press, New Delhi.

Hilton-Taylor, C. (compiler) (2000) 2000 IUCN Red List of Threatened Species. IUCN, Gland, Switzerland and Cambridge, UK.

Kock, R., Spala, P., Eva, J., Bircher, P., Ricketts, M. \& Stevenson, M. (1989) New ideas for red panda diets. In Red Panda Biology (ed. A.R. Glatston), pp. 57-71. SPB Academic Publishing, The Hague.

Kurt'en, B. \& Anderson, E. (1980) Pleistocene Marmals of North America. Columbia University Press, New York.

Lu, B., Glatston, A.R. \& Princee, F.P.G. (1993) Demographic and genetic analysis of the studbook population of Ailurus Fulgens
Styani. In Red or Lesser Panda Studbook, no. 7 (ed. A.R. Glatston), pp. 30-36. Stichting Koninklijke Rotterdamsediergarde, Rotterdam.

Macdonald, D. (ed.) (1984) The Encyclopaedia of Mammals. 2 Volumes. George Allen \& Unwin, London \& Sidney.

Mahapatra, R. (1998) Beauty and biology: the Shangri-la. Down to Earth, 7, 27-37.

Martin, L.D. (1989) Fossil history of the terrestrial carnivora. In Carnivore Behaviour, Ecology and Evolution (ed. J. L. Gittleman), pp. 536-568. Chapman \& Hall, London.

Munro, G. (1969) Breeding the lesser panda in Bremen zoo, Germany. International Zoo News, 89, 281-283.

Prater, S.H. (1948) The Book of Indian Animals. Bombay Natural History Society, Bombay [reprinted with corrections, 1980].

Rabinowitz, A. \& Khaing, S.T. (1998) Status of selected mammal species in northern Myanmar. Oryx, 32, 201-208.

Roberts, M. (1996) Biology of the red panda - general summary. In Proceedings of the Training Workshop: Conservation Management of Red Panda, pp. 7-42. Zoo Outreach Organisation \& Central Zoo Authority, Coimbatore \& Delhi.

Roberts, M. \& Gittleman, J.L. (1984) Ailurus fulgens. Mammalian Species, 222, 1-8.

Sarich, V.M. (1976) Transferrin. Transactions of the Zoological Society of London, 33, 165-171.

Tedford, R.H. \& Gustafson, E.P. (1977) First North American record of the extinct Parailurus. Nature, 265, 621-623.

TRAFFIC (IUCN/WWF) (1991) The Smuggling of Endangered Wildlife Across the Taiwan Strait. TRAFFIC International, Cambridge, UK.

Wang, M. (1989) Survey Reports on Habitat of Giant Pandas in China. Sichuan Forestry Bureau, Chengdu [in Chinese].

Warnell, K., Crissey, S. \& Oftedal, O. (1989) Utilization of bamboo and other fiber sources in red panda diets. In Red Panda Biology (ed. A.R. Glatston), pp. 51-56. SPB Academic Publlishing, The Hague.

Wei, F. (1997) Habitat selection, foraging and energetic strategies of giant and red pandas in Xiangling mountains. PhD thesis, Institute of Zoology. Chinese Academy of Sciences [in Chinese].

Wei, F., Feng, Z., Wang, Z. \& Hu, J. (1998) Assessment on the current status of the red panda in China. Small Carnivore Conservation, 18, 1-4.

Yonzon, P.B. \& Hunter, M.L. Jr (1991) Conservation of the red panda Ailurus fulgens. Biological Conservation, 57, 1-11.

\section{Biographical sketch}

Dr Anwaruddin Choudhury is a civil servant now working as the Director of Tea, Government of Assam. He received his $\mathrm{PhD}$ for research on primates in 1989, and is the honorary Chief Executive of the Rhino Foundation of northeast India. He is a member of the Asian Rhino, Cat, Small Carnivore, Threatened Waterfowl, and Water Bird IUCN/ SSC Specialist Groups, and WPA/BLI/SSC Pheasant Specialist Group. He is particularly interested in the survey and conservation of the wildlife of north-eastern India. 